\title{
PERAN ORIENTASI KESADARAN SOSIAL TERHADAP KARAKTERISTIK DAN REAKSI UMPAN BALIK
}

\author{
Sartika Zumria ${ }^{1}$, P. Tommy Y.S. Suyasa ${ }^{2}$, \& Bonar Hutapea ${ }^{2}$, \\ ${ }^{1}$ Program Studi Magister, Fakultas Psikologi, Universitas Tarumanagara, Jakarta \\ Email: sartika.707171002@stu.untar.ac.id \\ ${ }^{2}$ Fakultas Psikologi, Universitas Tarumanagara, Jakarta \\ Email: tommys@fpsi.untar.ac.id \\ ${ }^{3}$ Fakultas Psikologi, Universitas Tarumanagara, Jakarta \\ Email: bonarh@fpsi.untar.ac.id
}

\begin{abstract}
ABSTRAK
Penelitian ini bertujuan untuk menguji peran orientasi kesadaran sosial sebagai moderator hubungan antara karakteristik umpan balik dan reaksi umpan balik. Umpan balik bagi karyawan menjadi salah satu hal yang dapat meningkatkan kinerja dan motivasi. Hasil penelitian mengenai umpan balik terdahulu menunjukkan bahwa reaksi karyawan terhadap umpan balik dapat dipengaruhi oleh proses pemberian umpan balik itu sendiri. Selain itu penelitian sebelumnya menunjukkan bahwa terdapat faktor lain yang dapat mempengaruhi bagaimana individu yang berbeda dapat bereaksi terhadap umpan balik, salah satunya adalah orientasi kesadaran sosial yang dimiliki tiap individu. Karakteristik umpan balik dalam penelitian ini terdiri dari kredibilitas pemberi umpan balik dan penyampaian umpan balik. Penelitian ini melibatkan 92 partisipan yang terdiri dari 23 laki-laki dan 69 perempuan. Partisipan merupakan karyawan yang bekerja di bidang layanan administrasi akademik di beberapa universitas di Jakarta. Sebanyak 60 orang (65\%) diantaranya bekerja di universitas swasta, sedangkan 32 orang lainnya (35\%) bekerja di universitas negeri. Berdasarkan hasil uji hipotesis didapatkan bahwa kredibilitas pemberi umpan balik dan penyampaian umpan balik terbukti dapat menjadi prediktor dari reaksi umpan balik pada karyawan layanan administrasi akademik. Penelitian ini juga menunjukkan bahwa orientasi kesadaran sosial tidak dapat menjadi moderator hubungan antara karakteristik umpan balik dan reaksi umpan balik pada karyawan layanan administrasi akademik.
\end{abstract}

Kata kunci: karakteristik umpan balik orientasi umpan balik, orientasi kesadaran sosial, reaksi umpan balik

\begin{abstract}
This study aims to examine the role of social awareness orientation as a moderator of the relationship between feedback characteristics and feedback reactions. Feedback for employees can improve performance and motivation. The results of previous studies on feedback indicate that employee reactions to feedback can be influenced by the process of feedback itself. In addition, previous studies have shown that there are other factors that can affect how different individuals react to feedback, one of which is the orientation of social awareness that every individual possesses. Feedback characteristics in this study consist of the credibility of the feedback provider and the delivery of feedback. The study involved 92 participants consisting of 23 men and 69 women. Participants are employees who work in the field of academic administrative services in several universities in Jakarta. As many as 60 people (65\%) of them work at private universities, while 32 others (35\%) work at public universities. Based on the results of the hypothesis test, it is found that the credibility of the feedback provider and the delivery of feedback are proven to be a predictor of feedback reactions in academic administrative service employees. This study also shows that social awareness orientation fails to become a moderator of the relationship between feedback characteristics and feedback reactions in academic administrative service employees.
\end{abstract}

Keywords: feedback characteristics, feedback orientation, social awareness orientation, feedback reaction

\section{PENDAHULUAN}

\section{Latar Belakang}

Memberikan pelayanan administrasi yang baik terbukti memiliki pengaruh yang signifikan terhadap tingkat kepuasan dan loyalitas mahasiswa (Irawaty, 2013; Yuliawan, 2017). Oleh sebab itu, setiap perguruan tinggi diharapkan selalu berusaha meningkatkan kualitas pelayanan administrasi agar semakin baik lagi. 
Agar pemberian layanan administrasi dapat terlaksana dengan baik, sumber daya manusia memegang peranan yang sangat penting. Berdasarkan hasil survey di salah satu perguruan tinggi swasta di Jakarta, karyawan administrasi dianggap masih memberikan pelayanan administrasi yang cukup baik. Tidak hanya memberikan pelayanan administrasi, karyawan layanan administrasi akademik bertanggung jawab memastikan seluruh kegiatan operasional perkuliahan dapat berjalan dengan baik.

Untuk memastikan layanan administrasi yang diberikan tetap terjaga dengan baik, organisasi diharapkan dapat terus memberikan evaluasi kinerja terhadap karyawan melalui umpan balik. Hattie dan Timperley (2007) dalam penelitiannya mengenai The Power of Feedback, mengemukakan bahwa umpan balik adalah informasi mengenai kinerja selama ini yang dibutuhkan agar si penerima mampu memperbaiki dan mengembangkan kemampuannya. Diungkapkan juga oleh Levy dan Williams (2004) bahwa umpan balik adalah alat yang dapat memfasilitasi kinerja karyawan untuk menjadi lebih baik. Umpan balik juga dianggap sebagai faktor yang penting dalam proses pembelajaran dan motivasi kerja (Ilgen, Fisher \& Taylor, 1979).

Setiap karyawan memiliki reaksi yang berbeda terhadap umpan balik yang diterima nya. Seperti yang dipaparkan oleh Chen, Liao, JianQiao, Wu, Weijiong, Zheng, dan Wei (2017), bahwa reaksi umpan balik seringkali diklasifikasikan reaksi afektif dan reaksi kognitif. Reaksi afektif adalah tentang apa yang dirasakan oleh penerima umpan balik, sedangkan reaksi kognitif adalah apa yang dipikirkan oleh penerima umpan balik.

Berdasarkan penelitian sebelumnya, terdapat beberapa faktor yang dapat mempengaruhi reaksi individu terhadap umpan balik, antara lain kepuasan terhadap umpan balik (Giles dan Mossholder, 1990; Keeping \& Levy, 2000), adanya manfaat yang dirasakan (Keeping \& Levy, 2000), dan apakah umpan balik yang diterima dirasa akurat dan tepat (Greller, 1978; Keeping \& Levy, 2000).

Selain membahas mengenai hal-hal yang dapat mempengaruhi reaksi umpan balik (feedback reactions), beberapa penelitian sebelumnya juga memaparkan bagaimana reaksi seseorang terhadap umpan balik dapat diprediksi melalui karakteristik umpan balik (feedback characteristics). Misalnya saja bagaimana umpan balik yang bersifat negatif dapat menghasilkan reaksi yang negatif (Elicker, Levy, \& Hall, 2006; Steelman \& Rutkowski, 2004) dan begitu juga sebaliknya (Elicker, et al., 2006).

Wang, Burlacu, Truxillo, James, dan Yao (2014) yang meneliti salah satu karakteristik umpan balik yaitu penyampaian umpan balik (feedback delivery) mengungkapkan bagaimana sebuah umpan balik disampaikan dapat mempengaruhi reaksi dari penerima umpan balik tersebut. Menurut Steelman et al. (2004), karakteristik umpan balik lainnya yang dapat mempengaruhi reaksi umpan balik adalah kredibilitas dari pemberi umpan balik kredibilitas pemberi umpan balik (source credibility). Hal ini menunjukkan bahwa penting bagi karyawan sebagai penerima umpan balik untuk yakin bahwa pemberi umpan balik merupakan individu yang dapat dipercaya dan memiliki pemahaman terhadap tanggung jawab pekerjaan mereka.

Meskipun beberapa referensi terdahulu cukup banyak membahas mengenai kompleksitas umpan balik, namun masih seringkali terdapat hasil penelitian yang tidak konsisten (Steelman et al., 2004; Gabriel, Frantz, Noelle \& Levy, Paul \& Hilliard, Adam, 2014). Selain itu, meski memaparkan hubungan antara reaksi umpan balik, orientasi kesadaran sosial (social awareness orientation), dan karakteristik umpan balik, dalam penelitiannya Wang et al. (2014) hanya mengambil beberapa karakteristik umpan balik yang dianggap relevan dengan setting 
performance appraisal, yaitu favorability of feedback, feedback delivery, dan feedback quality. Padahal seperti yang dijelaskan oleh Steelman et al. (2004) bahwa karakteristik-karakteristik proses pemberian umpan balik (Feedback Environment) sesungguhnya lebih dari sebuah sesi formal penilaian kinerja, tetapi lebih kepada interaksi sehari antara atasan-bawahan atau sesama rekan kerja. Akibatnya penelitian yang dilakukan Wang et al. (2014) menjadi terbatas hanya dalam sesi performance appraisal saja sehingga tidak dapat menjelaskan gambaran karakteristik umpan balik lainnya.

Hal ini membuat peneliti kemudian tertarik untuk meilhat bagaimana hubungan antara reaksi umpan balik, orientasi kesadaran sosial, dan karakteristik umpan balik apabila tidak dibatasi dengan setting performance appraisal saja. Selain itu, peneliti juga melihat peluang untuk mengembangkan hasil penelitian Wang sebelumnya (Wang et al., 2014) baik dari segi perbedaan karakteristik partisipan maupun dimensi dari karakteristik umpan balik yang berbeda.

\section{Rumusan Masalah}

Berdasarkan paparan latar belakang diatas, peneliti tertarik untuk melihat apakah orientasi kesadaran sosial dapat berperan sebagai moderator hubungan kredibilitas pemberi umpan balik dan penyampaian umpan balik terhadap reaksi umpan balik pada karyawan layanan administrasi akademik. Adapun hipotesis dalam penelitian ini terbagi menjadi 4, antara lain, hipotesis 1 dimensi kredibilitas pemberi umpan balik terbukti memiliki hubungan positif dengan reaksi umpan balik. Hipotesis 2 adalah dimensi penyampaian umpan balik terbukti memiliki hubungan positif dengan reaksi umpan balik. Hipotesis 3 adalah orientasi kesadaran sosial dapat menjadi moderator hubungan antara kredibilitas pemberi umpan balik terhadap reaksi umpan balik, sedangkan hipotesis 4 adalah orientasi kesadaran sosial dapat menjadi moderator hubungan antara penyampaian umpan balik terhadap reaksi umpan balik.

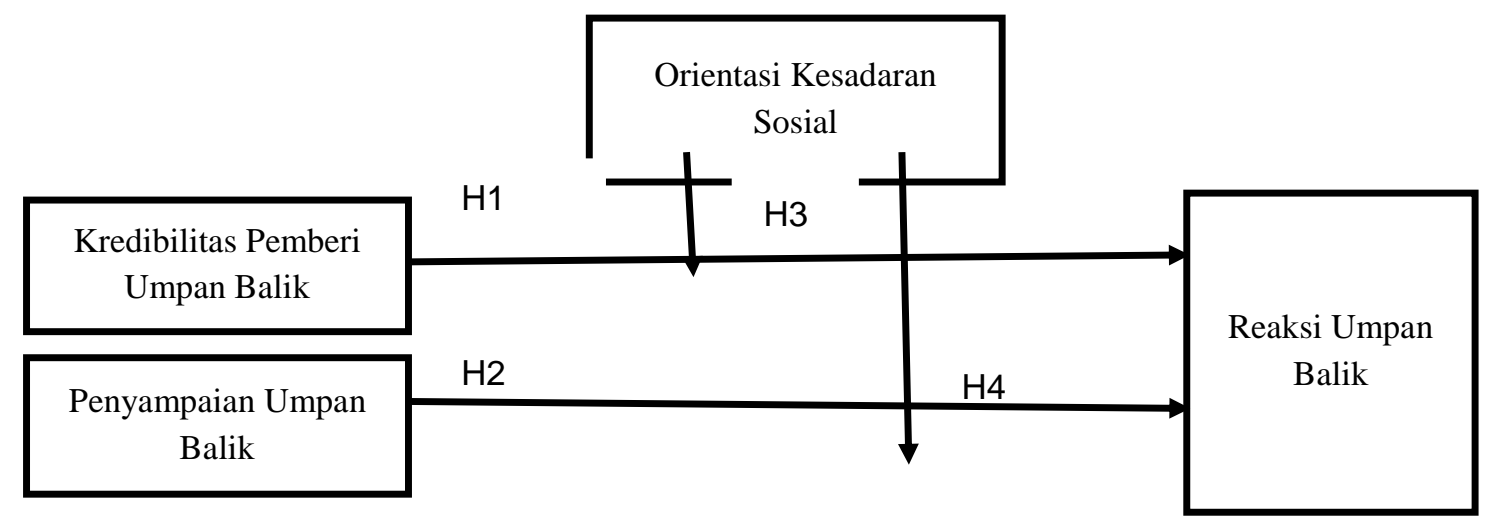

Gambar 1. Kerangka Berpikir

\section{METODE PENELITIAN}

\section{Partisipan dan Prosedur Penelitian}

Partisipan dalam penelitian ini merupakan karyawan yang berprofesi sebagai layanan administrasi akademik di universitas swasta dan negeri. Teknik sampling yang digunakan dalam penelitian ini adalah convenience sampling dimana kuisioner diberikan kepada partisipan yang dianggap sesuai dengan kriteria penelitian. Pengambilan data dilakukan dalam bentuk pembagian kuisioner hardcopy maupun link google form. 
Pengambilan data dimulai sejak tanggal 24 Oktober 2018 hingga 17 November 2018. Dalam pelaksanannya terkumpul sejumlah 102 partisipan, namun 10 diantaranya gugur berdasarkan hasil uji validitas. 92 partisipan yang berhasil dikumpulkan terdiri dari 23 (25\%) laki-laki dan 69 (75\%) perempuan, dengan sebagian besar berlatar belakang pendidikan S1 (67\%). Dari segi usia, partisipan terbagi menjadi $50(54 \%)$ berusia 19-29 tahun, $32(35 \%)$ berusia 30-39 tahun, 7 (8\%) berusia 40-49 tahun, dan $3(3 \%)$ berusia 50-54 tahun. Level jabatan partisipan dalam penelitian ini terdiri dari $51(55 \%)$ berada di level Staff, 27 (29\%) level Officer, 9 (10\%) level Supervisor, dan $5(5 \%)$ berada di level Manager. Partisipan terdiri dari $60(65 \%)$ bekerja di universitas swasta dan $32(35 \%)$ bekerja di universitas negeri. Sedangkan untuk lama bekerja terdiri dari 9 $(10 \%)<1$ tahun, $62(67 \%)$ bekerja selama 1-5 tahun, dan $21(23 \%)$ telah bekerja selama lebih dari 5 tahun.

\section{Pengukuran/Instrument Penelitian/Pedoman Observasi dan Wawancara}

Alat ukur yang digunakan dalam penelitian ini merupakan adaptasi dari beberapa penelitian sebelumnya tentang feedback, seperti Feedback Environment Scale (FES) dan Feedback Orientation Scale (FOS). Kuisioner dibuat dalam bentuk online (Google Form) dan kemudian disalin dalam bentuk hardcopy untuk dibagikan secara langsung kepada partisipan yang lebih memilih mengisi secara offline.

Kuisioner dalam penelitian ini terbagi menjadi empat bagian. Bagian pertama adalah informed consent, lalu bagian kedua dan seterusnya merupakan alat ukur tiga variabel penelitian, yaitu reaksi umpan balik, orientasi kesadaran sosial, dan feedback environment. Partisipan kemudian diminta untuk memilih setiap item alat ukur menggunakan skala Likert 1-5 (1 = Sangat Tidak Setuju, 2 = Tidak Setuju, 3 = Ragu-Ragu, 4 = Setuju 5 = Sangat Setuju).

Mengacu pada beberapa penelitian sebelumnya (Wang et al., 2014; Elicker et al., 2006; Keeping \& Levy, 2000), untuk mengukur variabel reaksi umpan balik dapat dilakukan melalui tiga dimensi. Dimensi tersebut antara lain, satisfaction with the feedback (Giles \& Mossholder, 1990; Keeping \& Levy, 2000; Wang et al., 2014), perceived utility (Greller, 1978; Keeping \& Levy, 2000; Wang et al., 2014), dan perceived accuracy (Keeping \& Levy, 2000; Stone, Gueutal, \& MacIntosh, 1984; Wang et al., 2014).

Ketiga dimensi reaksi umpan balik tersebut masing-masing diukur melalui 4 item yang telah di adaptasi, yang kemudian dibagi menjadi dua item positif dan dua item negatif. Contoh butir dari dimensi perceived utility adalah "saya merasa melalui umpan balik yang diberikan dapat membantu memperbaiki kinerja saya". Contoh butir dimensi perceived accuracy adalah "saya merasa umpan balik yang diberikan sesuai dengan kinerja saya selama ini". Sedangkan contoh butir dimensi satisfaction with the feedback adalah "saya merasa puas dengan umpan balik yang diberikan oleh atasan saya". Berdasarkan nilai outer loading yang diperoleh dari analisa menggunakan PLS, peneliti kemudian mengeliminasi butir item dengan nilai dibawah 0,5 sehingga yang tersisa adalah sebanyak 10 butir. Nilai Cronbach's alpha alat ukur reaksi umpan balik pada dua model tersebut juga tergolong reliabel $(0,901)$.

Untuk variabel orientasi kesadaran sosial, instrumen penelitian yang digunakan merupakan adaptasi dari Feedback Orientation Scale (FOS) yang disusun oleh Linderbaum dan Levy (2010). Item yang digunakan terdiri dari 8 butir dengan salah satu contoh butir nya adalah "saya berusaha untuk lebih sadar dan peduli dengan apa yang orang lain pikirkan tentang saya”. 
Delapan butir tersebut kemudian dibagi menjadi 5 butir positif dan 3 butir negatif. Peneliti kemudian melakukan analisa 8 butir item variabel orientasi kesadaran sosial menggunakan PLS dalam dua model. Model pertama adalah untuk melihat hubungan antara reaksi umpan balik, orientasi kesadaran sosial, dan kredibilitas pemberi umpan balik. Berdasarkan hasil tersebut, peneliti kemudian mengeliminasi butir item dengan nilai dibawah 0,5 sehingga yang tersisa adalah sebanyak 7 butir. Model kedua adalah untuk melihat hubungan antara reaksi umpan balik, orientasi kesadaran sosial, dan penyampaian umpan balik. Berdasarkan hasil tersebut, peneliti kemudian mengeliminasi butir item dengan nilai dibawah 0,5 sehingga yang tersisa adalah sebanyak 7 butir. Nilai Cronbach's alpha alat ukur reaksi umpan balik pada dua model tersebut juga tergolong reliabel $(0,835)$.

Instrumen penelitian yang digunakan untuk mengukur karakteristik umpan balik menggunakan Feedback Environment Scale (FES) dari Steelman, Levy, dan Snell (2004). Dimensi kredibilitas pemberi umpan balik terdiri dari 5 butir (3 item positif dan 2 item negatif). Contoh butir nya adalah "saya percaya bahwa umpan balik yang diberikan oleh atasan saya adalah benar". Sedangkan dimensi penyampaian umpan balik berjumlah 5 item, yang terdiri dari 3 item positif dan 2 item negatif. Contoh butir pertanyaannya adalah "atasan saya bersikap baik ketika memberikan umpan balik kepada saya". Dengan demikian total item untuk independent variable, karakteristik umpan balik pada penelitian berjumlah 10 item.

Peneliti kemudian melakukan analisa dua dimensi karakteristik umpan balik tersebut dalam dua model terpisah menggunakan PLS. Model yang pertama untuk melihat hubungan dimensi kredibilitas pemberi umpan balik dengan orientasi kesadaran sosial dan reaksi umpan balik. Analisa dilakukan sebanyak satu kali dimana semua item memiliki nilai dibawah 0,5. Model yang kedua untuk melihat hubungan dimensi penyampaian umpan balik dan reaksi umpan balik dengan orientasi kesadaran sosial sebagai moderator. Analisa dilakukan sebanyak satu kali dimana semua item memiliki nilai dibawah 0,5. Nilai Cronbach's alpha alat ukur reaksi umpan balik pada dua model tersebut juga tergolong reliabel $(0,828)$.

\section{HASIL DAN PEMBAHASAN}

Penelitian ini menggunakan desain penelitian kuantitatif non eksperimental. Dikarenakan hasil uji normalitas menggunakan SPSS menunjukkan seluruh variabel yang ada dalam penelitian ini berdistribusi tidak normal, maka analisis data dilanjutkan dengan statistik non-parametrik menggunakan bantuan aplikasi PLS dan SPSS untuk melihat korelasi antara ketiga variabel penelitian.

Gambaran mengenai reaksi umpan balik pada karyawan layanan administrasi diperoleh dengan cara analisis descriptive statistic. Melalui perhitungan tersebut didapatkan standar deviasi atau nilai simpangan baku sebesar 1,068 dan nilai rata-rata atau Mean $=3,76$. Skala kontinum untuk variabel reaksi umpan balik adalah 1 sampai dengan 5, sehingga nilai tengah atau Median $=3$. Hal ini menunjukkan bahwa reaksi umpan balik pada karyawan layanan administrasi tergolong tinggi. Nilai Mean untuk setiap dimensi dari variabel reaksi umpan balik dapat dilihat pada Tabel 11 dibawah ini.

Tabel 1

Nilai mean dan standar devasi dari tiap dimensi karakteristik

\begin{tabular}{lcc}
\hline \multicolumn{1}{c}{ Dimensi } & Mean & Standar Deviasi \\
\hline Kepuasan Terhadap Umpan Balik & 3,88 & 1,099 \\
Perceived Utility & 3,63 & 1,095 \\
Perceived Accuracy & 3,79 & 1,009 \\
\hline
\end{tabular}


Gambaran variabel orientasi kesadaran sosial pada karyawan layanan administrasi diperoleh dengan cara analisis descriptive statistic. Hasilnya didapatkan standar deviasi atau nilai simpangan baku sebesar 1,142 dan nilai rata-rata atau Mean $=3,84$. Skala kontinum untuk variabel orientasi kesadaran sosial adalah 1 sampai dengan 5 , sehingga Median nya $=3$. Sedangkan gambaran gambaran mengenai karakteristik umpan balik pada karyawan layanan administrasi diperoleh dengan cara analisis descriptive statistic. Melalui perhitungan tersebut didapatkan standar deviasi atau nilai simpangan baku sebesar 1,060 dan nilai rata-rata atau Mean $=3,93$. Skala kontinum untuk variabel karakteristik umpan balik adalah 1 sampai dengan 5, sehingga nilai tengah atau Median $=3$. Hal ini menunjukkan bahwa karakteristik umpan balik pada karyawan layanan administrasi tergolong tinggi. Nilai Mean untuk setiap dimensi dari variabel karakteristik umpan balik dapat dilihat pada Tabel 2 dibawah ini.

Tabel 2

Nilai mean dan standar devasi dari tiap dimensi karakteristik umpan balik

\begin{tabular}{lcc}
\multicolumn{1}{c}{ Dimensi } & Mean & Standar Deviasi \\
\hline Kredibilitas Pemberi Umpan Balik & 3,94 & 1,015 \\
Penyampaian Umpan Balik & 3,91 & 1,105 \\
\hline
\end{tabular}

\section{Uji Hipotesis}

Untuk menguji hipotesis peneliti menggunakan software PLS, baik untuk melihat hubungan antara dimensi karakteristik umpan balik dan reaksi umpan balik, maupun untuk melihat peran orientasi kesadaran sosial terhadap keduanya. Tahapan selengkapnya akan dijelaskan dalam Tabel 3.

Tabel 3

Hasil uji karakteristik umpan balik sebagai prediktor dari reaksi umpan balik

\begin{tabular}{lccc}
\hline \multicolumn{1}{c}{ Dimensi } & Nilai t & Nilai B & Nilai p \\
\hline Kredibilitas Pemberi Umpan Balik & 13,139 & 0,720 & 0,000 \\
Penyampaian Umpan Balik & 13,862 & 0,716 & 0,000 \\
\hline
\end{tabular}

Dalam Tabel 3 dapat dilihat bahwa kedua dimensi karakteristik umpan balik tersebut berfungsi sebagai prediktor dari reaksi umpan balik. Hal ini dapat dilihat dari nilai $p$ untuk kedua dimensi tersebut berada dibawah 0,05. Dengan demikian, hipotesis 1 dan 2 yang berbunyi karakteristik umpan balik dapat memprediksi reaksi umpan balik berhasil dibuktikan.

\section{Peran Orientasi Kesadaran Sosial sebagai moderator antara Karakteristik Umpan Balik dengan Reaksi Umpan Balik}

Dalam melihat peran orientasi kesadaran sosial sebagai moderator antara karakteristik umpan balik, peneliti melakukan analisis menggunakan software PLS dan SPSS. Proses analisis nya dapat dilihat pada Tabel 4 dibawah ini.

Tabel 4

Hasil uji orientasi kesadaran sosial sebagai moderator antara karakteristik umpan balik dan reaksi umpan balik

\begin{tabular}{lccc}
\hline \multicolumn{1}{c}{ Tahapan Uji Regresi } & Nilai t & Nilai B & Nilai p \\
\hline Pengujian Tahap 1 & & & \\
\hline Kredibilitas Pemberi Umpan Balik X Reaksi Umpan Balik & 0,665 & $-0,046$ & 0,506 \\
Penyampaian Umpan Balik X Reaksi Umpan Balik & 0,440 & $-0,033$ & 0,660 \\
\hline Pengujian Tahap 2 - Orientasi Kesadaran Sosial Tinggi & & & \\
\hline Kredibilitas Pemberi Umpan Balik X Reaksi Umpan Balik & $-0,756$ & $-0,160$ & 0,455 \\
Penyampaian Umpan Balik X Reaksi Umpan Balik & $-0,383$ & $-0,102$ & 0,704 \\
\hline Pengujian Tahap 2 - Orientasi Kesadaran Sosial Rendah & & & \\
\hline
\end{tabular}




\begin{tabular}{llll}
\hline Kredibilitas Pemberi Umpan Balik X Reaksi Umpan Balik & 1,068 & 0,629 & 0,293 \\
Penyampaian Umpan Balik X Reaksi Umpan Balik & 1,143 & 0,835 & 0,261 \\
\hline
\end{tabular}

Berdasarkan hasil uji menggunakan PLS, dapat dilihat bahwa orientasi kesadaran sosial tidak berfungsi sebagai moderator baik pada dimensi kredibilitas pemberi umpan balik ( $\mathrm{p}=0,506>$ $0,05)$ maupun dimensi penyampaian umpan balik $(\mathrm{p}=0,660>0,05)$. Artinya orientasi kesadaran sosial tidak memiliki hubungan yang signifikan sebagai moderator hubungan kredibilitas pemberi umpan balik dan penyampaian umpan balik terhadap reaksi umpan balik.

Selanjutnya peneliti melakukan analisis regresi linear menggunakan program SPSS untuk melihat signifikansi hubungan kredibilitas pemberi umpan balik dan penyampaian umpan balik terhadap reaksi umpan balik pada tingkat orientasi kesadaran sosial tinggi maupun rendah. Hasilnya didapatkan bahwa orientasi kesadaran sosial tidak berfungsi sebagai moderator pada kredibilitas pemberi umpan balik dan penyampaian umpan balik terhadap reaksi umpan balik pada karyawan layanan administrasi yang memiliki orientasi kesadaran sosial yang tinggi ataupun rendah. Dengan demikian, hipotesis 3 dan 4 yang berbunyi orientasi kesadaran sosial dapat menjadi moderator hubungan antara kredibilitas pemberi umpan balik dan penyampaian umpan balik pada reaksi umpan balik tidak berhasil dibuktikan.

\section{KESIMPULAN DAN SARAN}

Berdasarkan hasil penelitian diatas, terdapat beberapa hal yang dapat disimpulkan dari penelitian ini. Pertama, reaksi umpan balik, orientasi kesadaran sosial, dan karakteristik umpan balik pada karyawan layanan administrasi bisa dikatakan tergolong tinggi. Hal ini menunjukkan bahwa karyawan layanan administrasi cukup familiar dan terbiasa dengan adanya pemberian umpan balik. Mereka juga sudah cukup sadar atas fungsi dan manfaat dari adanya pemberian umpan balik.

Kedua, karakteristik umpan balik (kredibilitas pemberi umpan balik dan penyampaian umpan balik) mampu memprediksi reaksi umpan balik karyawan layanan administrasi. Artinya para karyawan layanan administrasi menganggap bahwa kredibilitas pemberi umpan balik dan penyampaian umpan balik merupakan hal yang penting yang dapat mempengaruhi reaksi mereka terhadap umpan balik yang diterima.

Ketiga, orientasi kesadaran sosial tidak mampu memoderasi hubungan antara karakteristik umpan balik dan reaksi umpan balik pada karyawan layanan administrasi. Hasil penelitian menunjukkan bahwa tinggi atau rendahnya orientasi kesadaran sosial pada karyawan layanan administrasi, tidak mampu memperkuat efek dari kredibilitas pemberi umpan balik dan penyampaian umpan balik dalam memprediksi reaksi umpan balik karyawan layanan administrasi.

\section{Saran}

Untuk penelitian selanjutnya mengenai umpan balik, khususnya yang berkaitan dengan reaksi umpan balik, orientasi kesadaran sosial, serta karakteristik umpan balik, terdapat beberapa hal yang dapat dipertimbangkan atau menjadi acuan penelitian selanjutnya. Pertama, penelitian selanjutnya dapat meneliti kepada karakter partisipan yang berbeda. Setelah sebelumnya Wang et al. (2014) melakukan penelitian kepada karyawan manufaktur di China, penelitian selanjutnya dapat diperluas lagi dengan karakter partisipan yang berbeda. 
Kedua, untuk penelitian selanjutnya yang ingin menggunakan karakter partisipan yang sama, yaitu karyawan layanan administrasi di universitas, dapat memperluas jangkauan penelitian diluar daerah Jabodetabek. Ketiga, perlu diperhatikan faktor budaya di Indonesia juga bisa menjadi faktor yang dapat mempengaruhi hasil penelitian, dimana Indonesia masih menganut budaya "sungkan" terhadap orang yang lebih tua atau orang yang dianggap lebih senior dari mereka.

Keempat, dalam penelitian mengenai umpan balik masih terdapat ruang pengembangan bila dikaitkan dengan teori-teori lainnya, seperti teori psikologi, teori sosial, ataupun teori manajemen. Dengan melakukan penelitian tentang umpan balik yang terkait dengan kajian bidang lain akan membantu memperkaya dan memperbanyak data mengenai umpan balik itu sendiri.

Kelima, meski berdasarkan hasil penelitian sebelumnya umpan balik dianggap dapat memberikan pengaruh yang signifikan terhadap perbaikan kinerja seseorang, namun masih banyak faktor lain yang dapat mempengaruhi apakah reaksi seseorang terhadap umpan balik dapat benar-benar meningkatkan kinerja karyawan. Berdasarkan feedback intervention theory yang dikemukakan oleh Kluger dan Denisi (1996), masih terdapat beberapa faktor lainnya yang dapat mempengaruhi bagaimana reaksi umpan balik positif dapat menghasilkan perubahan perilaku kerja yang positif pula. Hal ini membuat proses yang terjadi setelah reaksi umpan balik muncul menjadi menarik untuk diteliti, ditambah lagi dengan masih minim nya referensi dan penelitian sebelumnya yang membahas bagaimana respon atau reaksi dari umpan balik dapat diterapkan menjadi perilaku kerja yang sesuai dan diinginkan.

Karyawan layanan administrasi diharapkan dapat menggunakan umpan balik yang diterima sebagai sarana untuk evaluasi diri. Umpan balik juga dapat menjadi salah satu cara untuk menjaga komunikasi yang baik dengan atasan, juga sebagai kontrol dari organisasi untuk dapat memastikan pelayanan administrasi yang diberikan sudah semaksimal mungkin. Sedangkan untuk atasan, umpan balik sebaiknya tidak dilihat sebagai sebuah beban atau tanggung jawab yang memberatkan. Umpan balik seharusnya dapat menjadi sebuah cara untuk memastikan komunikasi atasan dan bawahan tetap terjaga dengan baik. Selain itu melalui umpan balik, atasan juga dapat mengukur sejauh mana pemahaman dan pengetahuannya tentang tanggung jawab pekerjaan bawahan. Umpan balik tidak hanya menjadi bentuk evaluasi diri bagi karyawan tetapi juga atasan sebagai pemberi umpan balik.

Kepada organisasi diharapkan untuk terus membentuk lingkungan yang berorientasi ada umpan balik. Untuk memastikan hal ini, organisasi dapat membuat program-program atau pelatihan untuk karyawan maupun atasan. Melalui hal ini, atasan akan semakin tahu bagaimana cara penyampaian umpan balik yang baik sehingga mencapai hasil yang diinginkan. Karyawan juga akan semakin paham bagaimana cara menyikapi umpan balik yang diterima, sehingga dapat meningkatkan motivasi dan kinerja sehari-hari.

\section{Ucapan Terima Kasih}

Ucapan terima kasih peneliti sampaikan kepada seluruh pihak universitas yang telah mengizinkan peneliti untuk melakukan pengambilan data. Lebih khususnya kepada seluruh partisipan yang telah bersedia meluangkan waktu dan telah bersedia untuk membantu penelitian ini melalui pengisian kuisioner, dari lubuk hati yang paling dalam peneliti ucapkan terima kasih. 


\section{REFERENSI}

Chen, X. \& Liao, J. \& Wu, W. \& Zheng, W. (2017). Perceived insider status and feedback reactions: a dual path of feedback motivation attribution. Frontiers in Psychology. 8. 10.3389/fpsyg.2017.00668.

Elicker, J. D., Levy, P. E., \& Hall, R. J. (2006). The role of leader-member exchange in the performance appraisal process. Journal of Management, 32(4), 531-551. http://dx.doi.or/10.1177/0149206306286622

Hattie, J., \& Timperley, H. (2007). The power of feedback. Review of Educational Research, 77(1), 81-112. https://doi.org/10.3102/003465430298487

Ilgen, D. \& Fisher, C. \& Susan, M. (1979). Consequences of individual feedback on behavior in organizations. Journal of Applied Psychology. 64. 349-371. 10.1037/0021-9010.64.4.349

Irawaty, D. (2013). Pengaruh kinerja dosen dan kualitas layanan administrasi akademik terhadap loyalitas mahasiswa pada politeknik LP3I Jakarta Kampus Sumber Arta. Jurnal Lentera Bisnis, 2(1), Mei 2013 / ISSN 2252-9993

Gabriel, A., Frantz, B. N., Levy, P. \& Hilliard, W. A. (2014). The supervisor feedback environment is empowering, but not all the time: feedback orientation as a critical moderator. Journal of Occupational and Organizational Psychology. 87. 487-506. 10.1111/joop. 12060

Giles, William F., \& Kevin W. Mossholder. (1990). Employee reactions to contextual and session components of performance appraisal. Journal of Applied Psychology. 75 (4). 371-377. 0021-9010/90

Greller, Martin M. (1978). The nature of subordinate participation in the appraisal interview. Academy of Management Journal. 21 (4). 646-658

Keeping, L. M., \& Levy, P. E. (2000). Performance appraisal reactions: Measurement, modeling, and method bias. Journal of Applied Psychology, 85(5), 708-723. http://dx.doi.org/10.1037/0021-9010.85.5.708.

Kluger, A. N., \& DeNisi, A. (1996). The effects of feedback interventions on performance: A historical review, a meta-analysis, and a preliminary feedback intervention theory. Psychological Bulletin, 119(2), 254-284. http://dx.doi.org/10.1037/00332909.119.2.254

Levy, P. E. \& Williams, J. R. (2004). The social context of performance appraisal: a review and framework for the future. Journal of Management. 30(6). 881-905. http://dx.doi.org/10.1016/j.jm.2004.06.005.

Linderbaum, B. A., \& Levy, P. E. (2010). The development and validation of the feedback orientation scale (FOS). Journal of Management, 36(6), 1372-1405. Retrieved from: http//dx.doi.org/10.1177/0149206310373145

Steelman, L. \& Rutkowski, A. K. (2004). Moderators of employee reactions to negative feedback. Journal of Managerial Psychology. 19. 6-18. 10.1108/02683940410520637

Steelman, L., Levy, P. \& Snell, F. A. (2004). The feedback environment scale: construct definition, measurement, and validation. Educational and Psychological Measurement EDUC PSYCHOL MEAS. 64. 165-184. 10.1177/0013164403258440.

Stone, D. L., Gueutal, H. G., \& McIntosh, B. (1984). The effects of feedback sequence and expertise of the rater on perceived feedback accuracy. Personnel Psychology, 37(3), 487506. http://dx.doi.org/10.1111/j.1744-6570.1984.tb00525.x

Wang, Mo \& Burlacu, Gabriela \& Truxillo, Donald \& James, Keith \& Yao, Xiang. (2014). Age differences in feedback reactions: the roles of employee feedback orientation social awareness and utility. The Journal of Applied Psychology. 100. 10.1037/a0038334 
Yuliawan, R. (2017). Pengaruh kualitas pelayanan pegawai administrasi akademik terhadap kepuasan mahasiswa. Jurnal Riset Ekonomi \& Bisnis. Vol. 12(2). 126-135. http://ejournal.stiedewantara.ac.id/index.php/001/article/view/85 